\title{
The Spectrum of Congenital Heart Diseases Operated at Shahid Gangalal National Heart Center in the last 5 Years.
}

\author{
Navin Chandra Gautam, Rabindra Bhakta Timala, Siddhartha Pradhan, Dikshya Joshi, Apoorva \\ Thakur, Nishesh Basnet, Marisha Aryal, Kanti Mahara, Dipesh Karki, Raamesh Koirala.
}

Department of Cardiovascular Surgery, Shahid Gangalal National Heart Center, Kathmandu, Nepal.

\section{Corresponding Author:}

Navin Chandra Gautam

Department of cardiovascular surgery, Shahid Gangalal National Heart Center, Kathmandu, Nepal.

E-mail: navincg@hotmail.com

ORCID ID NO: 0000-0003-2416-4096

Submitted date: $26^{\text {th }}$ November 2020

Accepted date: $3^{\text {rd }}$ March 2021

Cite this article as: Gautam N C, Timala R B, Pradhan S, et al. The Spectrum of Congenital Heart Diseases Operated at Shahid Gangalal National Heart Center in the last 5 Years. Nepalese Heart Journal 2021; Vol 18 (1): 13-17.

\section{Abstract}

Background and Aims: The spectrum of congenital heart diseases (CHD) presenting for surgery to any cardiac center varies depending upon the geographical location of the center. This study is aimed to reveal the spectrum of CHD operated at a tertiary level cardiac center of Nepal.

Methods: This is a retrospective study conducted at the Department of Cardiovascular Surgery at Shahid Gangalal National Heart Center (SGNHC), Kathmandu, over a period of five years, from April 14, 2015 to April 13, 2020. All patients with a confirmed diagnosis of congenital heart disease who had undergone palliative or definitive cardiac surgery were included.

Results: Out of the total 2698 patients, there were 1374 (50.93\%) females. The total number of acyanotic congenital heart disease was $1919(71.13 \%)$, and that of cyanotic was $779(28.87 \%)$. Male to female ratio among acyanotic and cyanotic were $0.85: 1$ and 1.31:1 respectively. Among all CHDs, atrial septal defect (ASD) (38.13\%) followed by ventricular septal defect (VSD) (21.68\%) and atrioventricular septal defect (AVSD) (5.04\%) respectively were the commonest acyanotic heart lesions. Considering only the pediatric population (age 0-18 years), the commonest was VSD $(27.06 \%)$ followed by ASD $(22.3 \%)$ respectively. The commonest cyanotic was tetralogy of Fallot (TOF) (14.15\%) followed by double outlet right ventricle (DORV) (4.44\%) and total anomalous pulmonary venous connection (TAPVC) $(2.89 \%)$ respectively.

Conclusion: Female population was slightly more in number amid acyanotic lesion whereas male population was dominant in cyanotic lesion. The commonest acyanotic CHD was ASD and, TOF was the commonest cyanotic lesion.

Keywords: Atrial Septal Defect; Cyanotic and Acyanotic Congenital Heart Disease; Tetralogy of Fallot; Ventricular Septal Defect.

DOI: https://orcid.org/10.3126/njh.v18i1.36770

\section{Introduction}

Congenital heart disease (CHD), in definition proposed by Mitchell et al, is “...a gross structural abnormality of the heart or intrathoracic great vessels that is actually or potentially of functional significance". ${ }^{1}$ The global prevalence of CHD at birth, in 2017, is 1.8 cases per 100 live births. ${ }^{2}$ Prevalence of CHD among school children in Kathmandu, Nepal is 1 per thousand and Atrial Septal Defect (ASD) was found to be the most common CHD. ${ }^{3,4}$

Different genetic and environmental factors affect the spectrum and prevalence of CHD worldwide. ${ }^{5}$ Right ventricle outflow tract obstruction lesions were found more in number in Asian population than in European and American population. ${ }^{6}$ Population-based study regarding spectrum of CHD in Nepal is unavailable. The hospitals-based study done at pediatric outpatient clinic had found Ventricular Septal Defect (VSD) the most common ayanotic and Tetralogy of Fallot (TOF) the most common cyanotic CHD. ${ }^{7,8}$ In our part of world, where the health care system is not optimized, early diagnosis and timely treatment of CHD, an important factor for reducing morbidity and mortality with CHD, is still uncommon.

To our knowledge, the spectrum of CHD undergoing surgery in any cardiac center of Nepal was not reported previously. The purpose of the study is to present a single-center evaluation of the spectrum of CHD operated at Shahid Gangalal National Heart Center (SGNHC), which is a tertiary level cardiac center performing yearly considerable portion of the total cardiac operations done in Nepal.

(a) Nepalese Heart Journal. Nepalese Heart Journal retain copyright and works is simultaneously licensed under Creative Commons Attribution License CC - By 4.0 that allows others to share the work with an acknowledge of the work's authorship and initial publication in this journal 
Considering the portion of cardiac operation done in this center, it can be said that the data represent the national level data till this date.

\section{METHOD}

This is a retrospective observational study conducted at the department of cardiovascular surgery at SGNHC, Kathmandu, Nepal, from April 14, 2015, to April 13, 2020. All patients with the confirmed diagnosis of CHD who had undergone definitive or palliative cardiac surgery were included. All age groups were included. Patients with multiple cardiac anomalies were also included. Patients with CHD associated with acquired heart disease were excluded.

Clinical data were reviewed from the patients' record file, intensive care unit record, perfusion sheet, and operation theater data. Consideration was given to the total number of CHD patients with age, sex and type of CHD. Age ranges were divided as neonates (028 days), infant (1 month to 1 year), toddler and preschool (above 1 year to 6 years), older children (above 6 years to 12 years), adolescent (above 12 years up-to 18 years) and adults (18 years and older). Cyanotic and acynotic CHDs were classified according to standard practice. ${ }^{9}$

\section{RESULTS}

There were a total of 2698 Congenital heart disease (CHD) diagnosed patients who had undergone palliative or definitive surgical procedures during the study duration. The total number of males were 1324 and female were 1374 . Male to female ratio among acyanotic and cyanotic were $0.85: 1$ and $1.31: 1$ respectively. The age ranged from 11days of neonate to 62 years among operated patients for CHD. The baseline distribution of CHD presented for surgery is summarized in table no 1 .
Table 1: Baseline distribution of CHD presented for surgery.

\begin{tabular}{|lll|}
\hline & Acyanotic & Cyanotic \\
\hline Male & 882 & 442 \\
\hline Female & 1037 & 337 \\
\hline Total & 1919 & 779 \\
\hline $0-28$ Days & 2 & 32 \\
\hline 1 Month-1 Year & 215 & 135 \\
\hline 1 yr-6 yrs & 430 & 339 \\
\hline 6 yrs-12 yrs & 341 & 138 \\
\hline 12 yrs-18 yrs & 254 & 87 \\
\hline$>18$ yrs & 677 & 48 \\
\hline
\end{tabular}

The commonest acyanotic CHDs were ASD followed by VSD and AVSD with $38.3 \%, 21.7 \%$, and $5.04 \%$ respectively, among all CHDs. Among the pediatric age group (that is $0-18$ years), VSD was the commonest acyanotic CHD (27.06\%). ASD diagnosed after 18 years of age comprises $589(21.8 \%)$ of all CHDs. There were two cases of supra-valvular aortic stenosis and one case of the dysplastic aortic valve. An eleven-day-old neonate with Coarctation of aorta was operated. The commonest age range for acyanotic operated cases was above 18 years of age $(35.3 \%)$, followed by 1-6 years of age $(22.4 \%)$. Age-wise distribution of acyanotic CHDs, along with total individual disease and percentage are shown in Table 2.

Table 2: Age-wise distribution of acyanotic CHDs along with total individual disease and percentage from all CHDs.

\begin{tabular}{|c|c|c|c|c|c|c|c|c|}
\hline Diagnosis & $\begin{array}{l}0-28 \\
\text { Days }\end{array}$ & $\begin{array}{l}1 \text { month- } \\
1 \mathrm{yr}\end{array}$ & $\begin{array}{l}1 \text { yrs- } \\
6 \text { yrs }\end{array}$ & $\begin{array}{l}6 \text { yrs- } \\
12 \text { yrs }\end{array}$ & $\begin{array}{l}12-18 \\
\text { yrs }\end{array}$ & $\begin{array}{l}>18 \\
\text { yrs }\end{array}$ & $\begin{array}{l}\text { Total no } \\
\text { of Individual }\end{array}$ & $\begin{array}{l}\text { Percentage } \\
\text { Among all CHD }\end{array}$ \\
\hline Ventricular Septal Defect (VSD) & & 143 & 228 & 84 & 79 & 51 & 585 & 21.68 \\
\hline Atrial Septal Defect (ASD) & & 7 & 120 & 179 & 134 & 589 & 1029 & 38.13 \\
\hline Patent Ductus Arteriosus (PDA) & & 6 & 29 & 19 & 10 & 13 & 77 & 2.85 \\
\hline Atrioventricular Septal Defect (AVSD) & & 33 & 30 & 49 & 13 & 11 & 136 & 5.04 \\
\hline Coarctation of Aorta (COA) & 1 & 7 & 10 & 4 & 6 & 7 & 35 & 1.29 \\
\hline $\begin{array}{l}\text { Congenitally Corrected Transposition of the } \\
\text { Great Arteries (CCTGA)/VSD }\end{array}$ & & 2 & 2 & 4 & & & 8 & 0.296 \\
\hline Aortopulmonary (AP) Window & & 2 & 1 & & & & 3 & 0.11 \\
\hline Interrupted Aortic Arch (IAA) & 1 & 1 & & & & & 2 & 0.074 \\
\hline $\begin{array}{l}\text { VSD, Right Ventricular Outflow Tract } \\
\text { Obstruction/Pulmonary Stenosis (RVOTO/PS) }\end{array}$ & & 7 & 3 & & 12 & 6 & 28 & 1.03 \\
\hline Subaortic Membrane & & 2 & 1 & 1 & & & 4 & 0.14 \\
\hline $\begin{array}{l}\text { Partial Anomalous Pulmonary Venous } \\
\text { Connection (PAPVC) }\end{array}$ & & 2 & 2 & & & & 4 & 0.14 \\
\hline Cortriatriatum & & 2 & 3 & & & & 5 & 0.18 \\
\hline Dysplastic Aortic Valve & & & 1 & & & & 1 & 0.037 \\
\hline Supra Aortic, Aortic Stenosis (AS) & & 1 & & 1 & & & 2 & 0.07 \\
\hline Total & 2 & 215 & 430 & 341 & 254 & 677 & 1919 & \\
\hline
\end{tabular}



the last 5 Years.

In cyanotic heart disease, TOF was the commonest with a total of $382(14.15 \%)$, followed by Double outlet right ventricle (DORV) 120 (4.44\%) and Total Anomalous Pulmonary Venous Connection (TAPVC) 78 (2.89\%). The commonest age range for presentation of cyanotic was 1-6 years of age (43.5\%). Among all Cyanotic CHD, TOF was 49\%. Age-wise distribution of cyanotic CHD, along with total of individual disease and percentage are presented in table 3.

Table 3: Age-wise distribution of cyanotic CHD, along with total of individual disease and percentage.

\begin{tabular}{|c|c|c|c|c|c|c|c|c|}
\hline Diagnosis & $\begin{array}{l}0-28 \\
\text { Days }\end{array}$ & $\begin{array}{l}1 \text { Month- } \\
1 \mathrm{yr}\end{array}$ & $\begin{array}{l}1 \mathrm{yr}- \\
6 \mathrm{yrs}\end{array}$ & $\begin{array}{l}6 \text { yrs- } \\
12 \text { yrs }\end{array}$ & $\begin{array}{l}12-18 \\
\text { yrs }\end{array}$ & $\begin{array}{l}>18 \\
\text { yrs }\end{array}$ & $\begin{array}{l}\text { Total of } \\
\text { Individual Disease }\end{array}$ & $\begin{array}{l}\text { Percentage } \\
\text { Among all CHD }\end{array}$ \\
\hline Tetralogy of Fallot (TOF) & & 17 & 212 & 72 & 55 & 26 & 382 & 14.15 \\
\hline $\begin{array}{l}\text { Total Anomalous Pulmonary Venous } \\
\text { Connection (TAPVC) }\end{array}$ & 3 & 33 & 21 & 17 & 3 & 1 & 78 & 2.89 \\
\hline $\begin{array}{l}\text { dextro-Transposition of the Great Arteries } \\
\text { (d-TGA) }\end{array}$ & 22 & 30 & 6 & 6 & & & 64 & 2.3 \\
\hline Tricuspid Atresia (TA)/VSD & & 13 & 13 & 13 & 1 & 1 & 41 & 1.51 \\
\hline Truncus Arterious & & 1 & & & & & 1 & 0.03 \\
\hline Pulmonary Atresia & 7 & 7 & 7 & 1 & 1 & & 23 & 0.85 \\
\hline Ebstein Anomaly & & 1 & 6 & 13 & 11 & 7 & 38 & 1.40 \\
\hline $\begin{array}{l}\text { Double Inlet Left Ventricle (DILV)/DIRV/ } \\
\text { Double-Outlet Left Ventricle (DOLV) }\end{array}$ & & 4 & 7 & 3 & 2 & 1 & 17 & 0.63 \\
\hline Double Outlet Right Ventricle (DORV) & & 25 & 61 & 9 & 14 & 11 & 120 & 4.44 \\
\hline VSD Critical RVOTO/PS & & 4 & 6 & 4 & & 1 & 15 & 0.55 \\
\hline Total & 32 & 135 & 339 & 138 & 87 & 48 & 779 & \\
\hline
\end{tabular}

\section{DISCUSSION}

This is the first review on the spectrum of CHD operated in Nepal, though this is from a single cardiac center, which is basically one of the only two major cardiac centers in the country for 30 million populations.

In the study male and female patients were almost equally distributed. When we analyzed only the pediatric age group (0-18 years), there were a total of 1973 cases of CHD: male 1058 (53.6\%) and female 915 (46.4\%). The male predominance among pediatric age group in our study is similar to that done by Zahid et al. (study population included up to the age of 16 years) at Rehman Medical Institute, Pakistan where males were $57.7 \%$ and females $42.2 \%{ }^{10}$ The study done by Mir AB et al, at tertiary care center of north India (study population $<14$ years of age) showed male $60 \%$ and female $40 \%$ with male dominance. ${ }^{11}$ In contradictory population based Chinese study (0-18 years included), about spectrum of $\mathrm{CHD}$, the girl population $(56.3 \%)$ dominated the male population $(43.8 \%){ }^{12}$

Our study is a hospital-based study. When we consider only pediatric population ( $0-18$ years) male dominance pattern may be due to our socio-economic status where male child is given more preference to female child. So, male patients were timely diagnosed and put to surgery. Maximum number of CHD among pediatric age ( 0 to 18 years) is operated between 1-6 years of age in both cyanotic $(46.3 \%)$ and acyanotic $(22.4 \%)$ CHD. The same was observed in the study done by Zahid et al. ${ }^{10}$

ASD was the most common CHD in this study with $38 \%$ of all CHDs. This result is consistent with the study conducted by Lakhotia et al. at the Institute of Medical Sciences, Banaras Hindu University, India where ASD comprised $40 \%$ of all CHD operated population, and it also included all age group. ${ }^{13}$

Among pediatric age group, VSD was the commonest type with $27 \%$ of CHD operated in our study which is consistent with the results of study from Pakistan done by Zahid et al. ${ }^{10}$ In his study he included pediatric population (but up to the age of 16 years) and VSD was the commonest CHD operated with $33.8 \%$. That VSD remains the commonest cardiac operation for pediatric population is supported by a publication of Hoffman et al. ${ }^{9}$

In our study, AVSD accounts for 5\% of total CHD. Regarding AVSD, our number is equal to that of a study conducted in newborn echo evaluation at Oman with 5.9\%. ${ }^{14}$ We included all form of AVSD in one category. Incidence of AVSD in our study was double that of an Indian study $(2.7 \%),{ }^{11}$ which also did not categorize the type of AVSD. Pakistani study with prevalence of AVSD $(10.3 \%),{ }^{10}$ included only complete type of AVSD. In general, the frequency of AVSD in studies from developing countries is reported between 3.5 and $8.8 \% .^{15}$ There is high association of Down's Syndromes with AVSD. Nearly $30-40 \%$ of Down's syndrome babies have associated AVSD. ${ }^{16}$ We do not know the incidence of down's syndrome in Nepal. Each year babies born with Down's syndrome are in increasing trend throughout the world.

In our study, the total number of PDA was $71(2.6 \%)$ among all age groups and $64(3.2 \%)$ among pediatric age group. This is far less than in the study done by Zahid et al. where PDA was $23.0 \%$ among pediatric age group. ${ }^{10}$ Reason behind the low number of PDA closure surgically in our study was that, in the last 5 years, our cardiologists did significant number of device closure for PDA.${ }^{17}$ Cardiologists, at our center are performing significant number of transcatheter closure of ASD as well as VSD. ${ }^{18,19}$ Overall, the impact of transcatheter closure of isolated cardiac lesion to the number of surgical closure in our center is not studied yet.

TOF being the commonest cyanotic occupied nearly $14.1 \%$ of all CHD and $49.3 \%$ of cyanotic CHD. This finding is comparable with the study (at surgical center with inclusion of $0-16$ years) done by Zahid et al., where TOF comprised $51.7 \%$ among cyanotic CHD. ${ }^{10}$ The study 
finding is similar to that of the study done at North India by Mir AB et al. (0-14 years) echocardiography based on suspected cardiac patient screening where the prevalence of TOF was $12.2 \%$ among all CHD. ${ }^{11}$

In our study, the right-side obstruction lesion (TOF, PS) has higher prevalence than the left side obstruction (CoA and AS) which is similar to descriptions made by Jacob et al. in the study done at Hong Kong, explaining white children seem to have more left ventricular obstructive lesions, whereas Asian children have more right ventricular outflow lesion. ${ }^{6}$

After TOF, DORV was the second commonest CHD with $4.4 \%$ of all CHD in this study. In general, DORV affects between $1 \%$ to $3 \%$ of people born with $\mathrm{CHD}^{20}$ Akin to our finding Mir AB et al. found DORV, $3.2 \%$ of total CHD in his study in a tertiary cardiac center of north India. ${ }^{11}$

Third commonest cyanotic CHD, in our study was TAPVC. TAPVC was $2.9 \%$ of all CHD. This finding is closer to that of a hospital-based study conducted at one of the children hospitals of Nepal by Shah GS et al., and TAPVC noted as the third commonest was $3.6 \%{ }^{21}$

In our series, d-TGA comprises the fourth commonest cyanotic at 2.4\%, among all CHD. A study from north India noted 3.3\% in the hospital-based $(<14$ years aged) screening suspected patient of CHD. ${ }^{11}$ Overall prevalence of d-TGA accounts for $5-7 \%$ of all congenital heart defects (CHD) with a prevalence of 0.2 per 1000 live births. ${ }^{22}$ This suggests that our d-TGA born children may not have reached hospital for diagnosis and further management.

\section{Limitation of the Study}

This is a single-center hospital-based review. Therefore, this study does not provide information on the prevalence of heart diseases in the general population of Nepal. Furthermore, this is a retrospective study; so, review of the hospital data, possibility of missing data, incomplete information may be there. While comparing with different publications, we even had to compare with papers studying echocardiography-based publication, some papers had included their study population up to 14 years, and some had included echocardiography based up to 18 years of age. We could not include data regarding the prevalence of Dextrocardia, Bicuspid aortic valve, and syndromic conditions. We could not categorize certain diseases though necessary, like DORV, Single Ventricle physiology. We included pentalogy under TOF. There is no definite definition of complex congenital heart disease; we did not use this terminology in our study for categorization of disease.

\section{CONCLUSION}

The commonest acyanotic CHD was ASD and, TOF was the commonest cyanotic lesion. Among pediatric age group, VSD was the commonest type of CHD. The findings of the study on spectrum of congenital heart diseases diagnosed at the center for surgery during the last five years corresponds well to the findings reported in other South-East-Asian countries. The study gives us an overview of the pattern of distribution of diseases operated for congenital heart surgery at Shahid Gangalal National Heart Center, Kathmandu, Nepal.

\footnotetext{
Sources of funding: None
} Conflict of interest: None

\section{References}

1. Mitchell SC, Korones SB, Berendes HW. Congenital heart disease in 56,109 births. Incidence and natural history. Circulation. 1971; 25:323-32.

https://doi.org/10.1161/01.CIR.43.3.323 PMid:5102136

2. Zimmerman M S, Carswell Smith A G, Sable C A. et al. Global, regional, and national burden of congenital heart disease, 1990-2017: a systematic analysis for the Global Burden of Disease Study 2017. The Lancet Child \& Adolescent Health, March 2020; vol 4(3):185-200. https://doi.org/10.1016/S2352-4642(19)30402-X

3. Prajapati D, Sharma D, Regmi PR. et al. Epidemiological survey of Rheumatic fever, Rheumatic heart disease and Congenital heart disease among school children in Kathmandu valley of Nepal. Nepalese heart journal 2013;10(1):1-5. https://doi.org/10.3126/njh.v10i1.9738

4. KC MB, Sharma D, Shrestha MB. et al, Prevalence of rheumatic and congenital heart disease in school children of Kathmandu valley Nepal. Indian Heart Journal 2003; 55(6):615-8. PMID: 14989511.

5. Lage K, Greenway SC, Rosenfeld JA, et al. Genetic and environmental risk factors in congenital heart disease functionally converge in protein networks driving heart development. Proc Natl Acad Sci U S A. 2012 Aug 28;109(35):14035-40. https://doi.org/10.1073/pnas.1210730109 PMid:22904188 PMCid:PMC3435181.

6. Jacobs E, Leung M. \& Karlberg J. Distribution of Symptomatic Congenital Heart Disease in Hong Kong. PediatrCardiol 2000; 21:148-157. https://doi.org/10.1007/s002469910025 PMid:10754087

7. Joshi A, Shrestha RP, Shrestha PS, et al. Pattern of Cardiac Diseases in Children Attended at Dhulikhel Hospital, Nepal. Kathmandu Univ Med J (KUMJ). 2016 JulSept.;14(55):239-243. PMID: 28814686.

8. Basnet NB. Congenital heart disease in Nepalese children. J Nep Med Assoc 2006;45(162):281-282.

https://doi.org/10.31729/jnma.516

9. Hoffman JL, Kaplan S. The incidence of congenital heart disease, Journal of the American College of Cardiology. 2002; 39 (12), 1890-1900. https://doi.org/10.1016/S0735-1097(02)01886-7

10. Zahid SB, Jan AZ, Ahmed S et al. Spectrum of congenital heart disease in children admitted for cardiac surgery at Rehman Medical Institute, Peshawar, Pakistan. Pak J Med Sci 2013;29(1):173-176. https://doi.org/10.12669/pjms.291.2910 PMid:24353534 PMCid:PMC3809184. 
11. Mir AB, Ahmed K, J Muzafar, et al. Spectrum of congenital heart disease in a tertiary care center of North India. Int J ContempPediatr 2019; 6:927-31.

https://dx.doi.org/10.18203/2349-3291.ijcp20191996

12. Liu F, Yang Y-N, Xie X, et al. (2015) Prevalence of Congenital Heart Disease in Xinjiang Multi-Ethnic Region of China. PLoS ONE 10(8): e0133961.

https://doi.org/10.1371/journal.pone.0133961 PMid:26317413 PMCid:PMC4552834.

13. Lakotia S, Mathur SK, Das NN et al. Surgical outcome of congenital heart disease cases: a single unit analysis in an upcoming center in eastern Uttar Pradesh, India. International Journal of Contemporary Medical Research 2016;3(6):18421844.

14. Subramanyan J, Joy P, Venugopalan A. et al. Al Khusaiby (2000) Incidence and spectrum of congenital heart disease in Oman, Annals of Tropical Paediatrics, 20:4, 337-341. https://doi.org/10.1080/02724936.2000.11748155 PMid:11219172.

15. Zuechner A, Mhada T, Majani NG. et al. Spectrum of heart diseases in children presenting to a paediatric cardiac echocardiography clinic in the Lake Zone of Tanzania: a 7 years overview. BMC Cardiovasc Disord 19, 291 (2019). https://doi.org/10.1186/s12872-019-01292-4 PMid:31835996 PMCid:PMC6909619.

16. Paladini D, Tartaglione A, Agangi A, et al. The association between congenital heart disease and Down syndrome in prenatal life. Ultrasound Obstet Gynecol. 2000 Feb;15(2):1048. https://doi.org/10.1046/j.1469-0705.2000.00027.x PMid:10775990.
17. Adhikari C, Bogati A, Acharya K, et al. Safety and Procedural Success of Transcatheter Closure of Patent Ductus Arteriosus in Adults at Shahid Gangalal National Heart Centre, Kathmandu, Nepal.NJHNov.2020;17(2):43-6. DOI: https://doi.org/10.3126/njh.v17i2.326791

18. Adhikari C, Shrestha M, Bogati A, et al . Recent experience on atrial septal defect device closure at Shahid Gangalal National Heart Centre, Kathmandu, Nepal. NJH [Internet]. 30Apr.2019 [cited 10Nov.2020];16(1):11-3. Available from: https://doi.org/10.3126/njh.v16i1.23891

19. Adhikari C, Shrestha M, Shah S, et al. Device closure of ventricular septal defect: Initial experience in Nepal. Asian Journal of Medical Sciences, 10(4), 23-27. https://doi.org/10.3126/ajms.v10i4.24176

20. Obler D, Juraszek Al, Smoot LB, et al. Double outlet right ventricle: aetiologies and associations. J. Med Genet. 2008 August ,45(8): 481-97. https://doi.org/10.1136/jmg.2008.057984 PMid:18456715

21. Shah GS, Singh MK, Pandey TR, et al. Incidence of congenital heart disease in tertiary care hospital. Kathmandu Univ Med J (KUMJ). 2008 Jan-Mar;6(1):33-6. PMID:18604112.

22. Villafañe J, Lantin-Hermoso MR, Bhatt AB, et al. D-transposition of the great arteries: the current era of the arterial switch operation. Journal of the American College of Cardiology, 64(5), 498-511.

https://doi.org/10.1016/j.jacc.2014.06.1150 PMid:25082585 PMCid:PMC4340094. 